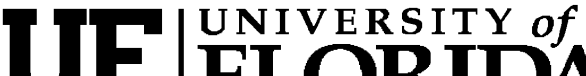 FLORIDA \\ IFAS Extension
}

\section{YOU and YOUR CREDIT: Managing Your Credit ${ }^{1}$}

\author{
Joan P. Elmore, Michael S. Gutter, and Travis P. Mountain ${ }^{2}$
}

Below are links to each of the YOU and YOUR CREDIT series.

Credit Dos and Don'ts: PDF version - http://edis.ifas.ufl.edu/pdffiles/FY/FY106400.pdf

Credit Card Basics: PDF version - http://edis.ifas.ufl.edu/pdffiles/FY/FY106500.pdf

Managing Your Credit: PDF version - http://edis.ifas.ufl.edu/pdffiles/FY/FY106700.pdf

Credit Scores: PDF version - http://edis.ifas.ufl.edu/pdffiles/FY/FY106800.pdf

Home Ownership and Credit: PDF version - http://edis.ifas.ufl.edu/pdffiles/FY/FY106900.pdf

Further Resources: PDF version - http://edis.ifas.ufl.edu/pdffiles/FY/FY107000.pdf

Series of Five Parts, Bound as Single Document: PDF version -

http://edis.ifas.ufl.edu/pdffiles/FY/FY107100.pdf

1. This document is FCS7231, one of a series of the Department of Family, Youth, and Community Sciences, Florida Cooperative Extension Service, Institute of Food and Agricultural Sciences, University of Florida. Original publication date September 22, 2008. Visit the EDIS Web site at http://edis.ifas.ufl.edu.

2. Joan P. Elmore, Extension Agent IV, Jackson County Extension, Marianna, Florida 32448; Michael S. Gutter, Financial Management State Specialist and Assistant Professor, and Travis P. Mountain, Lecturer, Department of Family, Youth, and Community Sciences, Institute of Food and Agricultural Sciences, University of Florida, Gainesville, Florida 32611.

The Institute of Food and Agricultural Sciences (IFAS) is an Equal Opportunity Institution authorized to provide research, educational information and other services only to individuals and institutions that function with non-discrimination with respect to race, creed, color, religion, age, disability, sex, sexual orientation, marital status, national origin, political opinions or affiliations. U.S. Department of Agriculture, Cooperative Extension Service, University of Florida, IFAS, Florida A. \& M. University Cooperative Extension Program, and Boards of County Commissioners Cooperating. Larry

Arrington, Dean 


\section{YOU and YOUR CREDIT: Managing Your Credit ${ }^{1}$}

Joan P. Elmore, Extension Agent IV, Jackson County Extension, Marianna, Florida 32448, Michael S. Gutter, Financial Management State Specialist, IFAS/UF, Travis P. Mountain, Lecturer, IFAS/UF ${ }^{2}$

\section{HOW MUCH DEBT CAN YOU REALISTICALLY CARRY?}

The debt service-to-income ratio compares your total annual debt repayments (including rent or mortgage) to your gross annual income (income before taxes and any deductions). A desirable ratio is .36 or less. For example, a household earning $\$ 40,000$ annually should not have debt payments totaling over $\$ 14,400$ per year.

\section{How much credit can you afford?}

Your gross income

$36 \%$ of your gross income
$\$$

$\$$

Source: USDA Rural Development

1. This document is FCS7231, one of a series of the Department of Family, Youth and Community Sciences, Florida Cooperative Extension Service, Institute of Food and Agricultural Sciences, University of Florida. First published: September 2008. Please visit the EDIS Web site at http://edis.ifas.ufl.edu.

2. Joan P. Elmore, Extension Agent IV, Jackson County Extension, Marianna, Florida 32448, Michael S. Gutter, Financial Management State Specialist, IFAS/UF, Travis P. Mountain, Lecturer, IFAS/UF.

The Institute of Food and Agricultural Sciences (IFAS) is an Equal Employment Opportunity-Affirmative Action Employer authorized to provide research, educational information and other services only to individuals and institutions that function without regard to race, creed, color, religion, age, disability, sexual orientation, marital status, national origin, political opinions, or affiliation. For information on obtaining other extension publications, contact your county Cooperative Extension Service office. Florida Cooperative Extension Service/Institute of Food and Agricultural Sciences/University of Florida/Larry R. Arrington, Dean. 
Managing

Your Credit

\section{CREDIT CARD WORKSHEET}

This worksheet can help you analyze your credit cards, costs, terms, conditions and your needs to select the best credit card(s) for you.

\begin{tabular}{|l|l|l|l|}
\hline INTEREST APR's & Card A & Card B & Card C \\
\hline Purchases & & & \\
\hline Cash Advances & & & \\
\hline Balance Transfers & & & \\
\hline
\end{tabular}

\begin{tabular}{|l|l|l|l|}
\hline INTEREST RATE & & & \\
\hline Fixed & & & \\
\hline Variable & & & \\
\hline Introductory & & & \\
\hline Tiered & & & \\
\hline
\end{tabular}

\begin{tabular}{|l|l|l|l|}
\hline GRACE PERIOD IF YOU: & & & \\
\hline Carry a balance & & & \\
\hline Pay off balance each month & & & \\
\hline Cash advances & & & \\
\hline
\end{tabular}

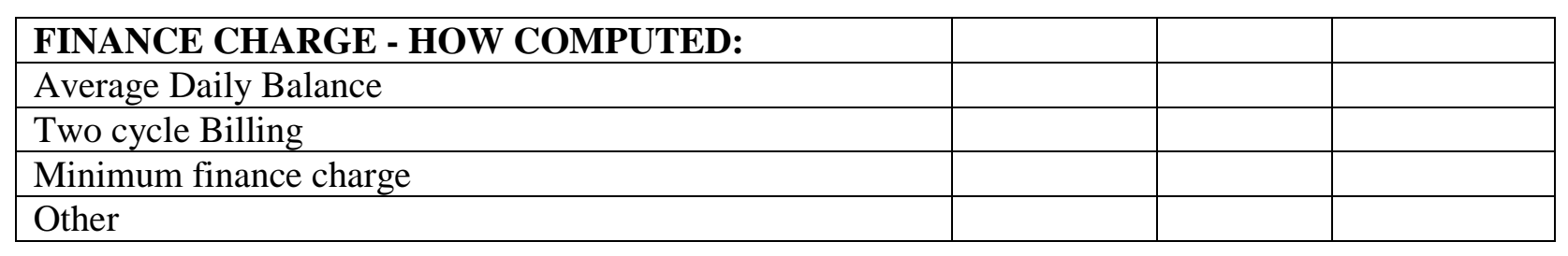

\begin{tabular}{|l|l|l|l|}
\hline ADDITIONAL FEES & & & \\
\hline Late Fees & & & \\
\hline Over the Limit & & & \\
\hline Annual & & & \\
\hline Other- & & & \\
\hline Other- & & & \\
\hline Other- & & & \\
\hline
\end{tabular}

\begin{tabular}{|l|l|l|l|}
\hline OTHER FEATURES & & & \\
\hline Rebates & & & \\
\hline Frequent flyer miles & & & \\
\hline Insurance & & & \\
\hline Other & & & \\
\hline
\end{tabular}

Source: Federal Reserve Bank 
Managing

Your Credit

\section{INVENTORY of Credit Cards and Loans}

It is important to keep this information in a secure place with your other valuable papers in case of an emergency like fire, hurricanes, etc.

\begin{tabular}{|l|l|l|l|l|l|l|}
\hline $\begin{array}{l}\text { Creditor } \\
\text { Name/address }\end{array}$ & Account \# & Phone \# & $\begin{array}{l}\text { Inter est } \\
\text { Rate }\end{array}$ & $\begin{array}{l}\text { Current } \\
\text { Balance }\end{array}$ & $\begin{array}{l}\text { Due } \\
\text { Date }\end{array}$ & $\begin{array}{l}\text { Monthly } \\
\text { Payment }\end{array}$ \\
\hline & & & & & & \\
\hline & & & & & & \\
\hline & & & & & & \\
\hline & & & & & & \\
\hline & & & & & & \\
\hline & & & & & & \\
\hline
\end{tabular}

Total Monthly Amount:

Date of Inventory:

Additional Comments 


\section{A CLOSER LOOK AT THE COST OF CREDIT - The Minimum Payment Trap}

Making Minimum Payment (4\% of amount borrowed)

\begin{tabular}{|l|l|l|l|l|l|}
\hline ITEM & $\begin{array}{l}\text { RETAIL } \\
\text { PRICE }\end{array}$ & $\underline{\text { APR }}$ & $\underline{\text { INTEREST PAID }}$ & $\begin{array}{l}\text { REALLY PAID } \\
\text { FOR ITEM }\end{array}$ & $\underline{\text { YEARS TO PAY OFF }}$ \\
\hline TV & $\$ 500$ & $18 \%$ & $\$ 216$ & $\$ 716$ & 4 years, 11 months \\
\hline Computer & $\$ 1,000$ & $18 \%$ & $\$ 516$ & $\$ 1,516$ & 7 years, 3 months \\
\hline Furniture & $\$ 2,500$ & $18 \%$ & $\$ 1,416$ & $\$ 3,916$ & 10 years, 3 months \\
\hline
\end{tabular}

This chart assumes you are not making additional purchases and you are making payments on time. You can call your credit card company and ask them for the number of years it will take to pay off the current balance if you only make the minimum payments.

Making More than the Minimum Payment-It Pays Off

\begin{tabular}{|l|l|l|l|l|l|}
\hline $\begin{array}{l}\text { ORIGINAL } \\
\text { BALANCE }\end{array}$ & $\underline{\text { APR }}$ & $\frac{\text { MONTHLY }}{\text { PAYMENTS }}$ & $\begin{array}{l}\frac{\text { TOTAL \# OF }}{\text { MONTHLY }} \\
\text { PAYMENTS }\end{array}$ & $\frac{\text { TOTAL YEARS TO }}{\text { PAY OFF }}$ & $\frac{\underline{\text { TOTAL OF }}}{\text { PAYMENTS }}$ \\
\hline$\$ 2,500$ & $18 \%$ & Minimum & 123 & 10 years & $\$ 3,916$ \\
\hline$\$ 2,500$ & $18 \%$ & Minimum + \$25 & 50 & 4 & $\$ 3,258$ \\
\hline$\$ 2,500$ & $18 \%$ & Minimum + \$50 & 33 & 3 & $\$ 2,839$ \\
\hline
\end{tabular}

This chart assumes you are not making additional purchases and you are making payments on time.

\section{REQUEST A LOWER INTEREST RATE}

If you have been with a credit card company for several years and are in good standing, you can request a lower interest rate. The steps include:

1. Dial the $\mathbf{8 0 0}$ number on the back of your card.

2. Use this sample script: Hi, my name is (your name). I have been a credit card holder with your company for the last (number) years. My account is in good standing and I would like to continue using it. However, I would like you to consider giving me a lower interest rate on this account, or I may switch to a card with a better rate.

3. Record the name of the person with whom you spoke, the date, your interest rate, and then a date six months later when you can make your request again. If they refuse to give you a lower rate, try again the next day to reach someone more helpful. After successfully lowering your interest rate, wait six months and ask again. 


\section{RECORD OF LOWER INTEREST RATE INQUIRIES}

\begin{tabular}{|c|c|c|c|c|c|}
\hline Credit card & Phone number & $\begin{array}{l}\text { Person you } \\
\text { spoke to }\end{array}$ & $\begin{array}{l}\text { Interest } \\
\text { Rate }\end{array}$ & Date & $\begin{array}{l}\text { Date to call } \\
\text { again }\end{array}$ \\
\hline & & & & & \\
\hline & & & & & \\
\hline & & & & & \\
\hline & & & & & \\
\hline & & & & & \\
\hline & & & & & \\
\hline & & & & & \\
\hline
\end{tabular}

Source: Bankrate.com

\section{BALANCE TRANSFERS - Know What You Are Getting}

Transferring a high-interest card to a card with a low rate can save a bundle of cash and speed up your path to lower your debt. But, be careful. The rules are different for each card.

1. Check the time limit. Most interest rates last only 6-9 months, then revert to a more traditional rate.

2. Know what the interest rate really covers. Does it cover just the balances transferred? Many exclude any new purchases made. The credit card company will apply all of your payment to the zero or low-rate balances first, until they are paid off. That means your new purchases will continue to revolve on the card and rack up the higher interest cost.

3. Beware of the hefty fees. Most cards have a balance transfer fee. The cost varies, so check it out. You want to consider only those cards that have a cap on their transfer fees.

4. Watch out for the bait and switch. Just because you applied for the zero percent rate doesn't mean you'll get it. Card companies will sometimes issue you the card but assign a higher rate if your credit score is low. Be sure to READ the agreement terms that come with the card before you transfer a balance or make a purchase.

5. Always pay on time. The zero rate or low rate will disappear the minute you are late. The interest rate can be bumped up to high as 30 percent plus the late fee. 
Managing

Your Credit

\section{WORKSHEET FOR BALANCE TRANSFER}

\section{OLD CARD}

Toll-free \# for customer service

Account \#

Balance

APR

Grace period

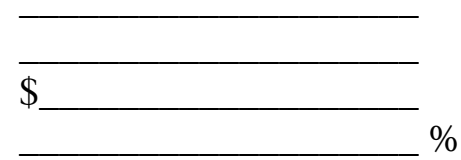

Due date

\section{NEW CARD}

Toll free \# for customer service

Account \#

Balance

Introductory APR

Date introductory rate expires

Date balance transfer APR expires

APR after introductory rate expires

APR after late payments

Balance transfer fee

Annual fee

Grace period

Due Date

Remember, while a balance transfer is pending, continue to make minimum payments by the due date to the old card. When you receive a billing statement from the old card, make sure it has a zero balance.

A helpful online tool is PowerPay. This tool helps consumers organizes their debts and make decisions about debt management, payoff schedules, consolidation, and how to most efficiently use additional funds to reduce debt. The program is available at www.powerpay.org. Your local Extension agent can help you get your information organized and interpret the program results. 